\title{
Value Education in Literature Traditional Bali as the Establishment of Reference Characters
}

\author{
NI Nyoman Karmini \\ Study Program of Indonesian and Local Languages, Faculty of Languages and Arts Education (FPBS) \\ Institute of Teacher Training and Education (IKIP) Saraswati, Tabanan, Bali Province, Republic of Indonesia
}

\begin{abstract}
The literature can provide lessons (docere), give pleasure (delectare), and is able to move the reader towards responsible activities (movere). Given this, the paper aims to describe the values education that can be used as a reference for the establishment of character. Data collected by the method of documentation with technical note, concretized by the method of ethics and emic. Furthermore, the data were analyzed by the method of hermeneutics, and the results are presented descriptively.
\end{abstract}

Keywords: education, literature, characters

\section{Introduction}

Developments in information technology today is very influential and bring about change in all aspects of life of human culture. Aspects of community life are manipulated to pursue advances in technology, which are believed to beable to improve the people's lives. It was just a "myth" that can not be accounted for (Sudewa, 2006:83). In fact now, cultural forms that have socio-cultural ties between the value of the arts and bearer community received less attention. People are increasingly feeling the gap between the physical and spiritual needs. Conflicts always occur, both covert and overt, inter-ethnic conflict, inter-religious flavored with conflicts of interest and primordial sentiments that often destabilize the Republic of Indonesia and led to the disruption of social life and harmony of the nation (Sutarto 2006 in Mulyani, 2012:119). Conflicts also occur because each ethnicity has an ideology that claims that the group is more superior than other ethnic groups As a result, the ethnic group that has a high ethnocentric attitudes will be prejudiced, do stereotyping, discrimination, and social distance toward other groups (Liliweri 2007 in Mulyani 2012:119).

By Balinese author/writer, tattwa (philosophy), susila (ethical), and acara (ritual) as the basic framework of the teachings of Hinduism are reflected in traditional Balinese literature. Balinese traditional literature is called Bali Purwa literature. Traditional Balinese literature such kakawin and canticles under the influence of Java and in accepting the influence, Bali could develop a more fertile source of influence (Creese 1998). Traditional Balinese literature also has a semiotic system, a system of interconnected meanings and can be interpreted according to the context of the situation and the cultural context. Balinese traditional literature also contains language, literature, and cultural codes (Halliday and Hasan (1994: 4, 62-63). Traditional Balinese literature has a distinctive shape as regional characteristics, such as tembang (poem), in the form of gancaran (prose), and shaped Palawakia (lyrical prose) (Tinggen, 1994:14; Karmini, 2008:2). Balinese traditional literature is usually sung. Therefore, the emerging concept is "malajah sambilang magending, magending sambilang malajah" (learning while singing, singing while learning) (Karmini, 2008: 3, Putra 2009). In traditional literature with new themes, either as outlined in geguritan narrative (story) and written in an instant couplet two good for ditembangkan in radio or television programs interactively, values delivered normally use contemporary issues such as drugs, corruption, or natural disasters (Putra, 2009; 2014; Putra and Creese 2012). For modern literature, literary Bali often received prestigious literary prizes such as the Equator Award, as obtained author Gde Aryantha Soethama, Sindhu Putra, and Oka Rusmini (Putra, 2011).

Literary work is a manifestation of human culture that can provide lessons (docere), give pleasure (delectare), and is able to move the reader towards responsible activities (movere). Literary works, both traditional and modern give an overview of the cultural life of its time. Cultural aspects that are reflected in the literature include, among others: religion, language, literature, art, and tradition where the literary works are created (Karmini, 2008: 2; Karmini, 2012: 142). Literature as a vehicle for expressing ideas, feelings, and beliefs, as well as a medium to convey ideas, theories, and systems of thinking (Karmini, 2011: 3). The values in the literature, especially values education is necessary to serve as the foundation of each individual character, such as to form a character that respects the environment. For example, by digging local wisdom of Bajo people. The people of Bajo regard the sea as a sacred place and inhabited by $M b o$ or God of the Sea. Before doing activities at sea, they always pray and perform a ceremony that consists of three slices of areca nut, betel leaf, lime betel, and a cigarette made of tobacco wrapped in nipa leaf. The ceremony is called maduai la intended that Mbo Lao protect and give them in abundance fortune during the fishing. There are some restrictions (taboos) that should not be violated when at sea. The pamali is related to the survival of the ecosystem and marine life, and there is also related to the safety of individuals and Bajo society in general (Bahtiar, 2012: 180).

To understand literature, imagination holds a very important role, even a work of literature is considered as awork that presents an imaginary world not the empirical world or historical reality. This means that literary work isa fiction (Kleden, 2004: 20). Therefore, the world described in the literature are fictitious and do not need to look for the truth in the real world. Fictional world described in the literature can be used as a reference for the formation characters 


\section{International Journal of Science and Research (IJSR) \\ ISSN (Online): 2319-7064 \\ Index Copernicus Value (2013): 6.14 | Impact Factor (2014): 5.611}

Character formation can be taught through the traditional Balinese learning literature, both prose and poetry. The assessment of a literary work depends on its structure, but the structure is not the only factor to assess. Value is in the work, but it just manifests when a reader questions it. Reading is not just an action to realize the work, but also an assessment process. This does not mean that the beauty of a work is given only by the reader; can not mean that the assessment process is only individual experiences; and can not mean that the consideration of the assessment is the subjective consideration in nature (Todorov, 1985: 67). Values education which evoked in the traditional literature, contains noble values that can be used as a reference in the formation characters. Someone who have good character will be able to live this life to achieve harmony of life. Therefore, the values of education as outlined in the traditional Balinese literature so need to be explored, understood, and applied by someone in order to establish his character.

In connection with the above description, this paper uses a work of literature in the form of prose titled I Ceker Cipak as an object of discussion. The problem is principally educational values anything that can be used as a reference for the formation of character. The purpose of this paper is to describe the educational values that can be used as a reference for the establishment character.

\section{Research Methodology}

To achieve this purpose, a documentation method is used supported by to recording techniques to collect the data, then concretized with ethic and emic methods, arguing with the view that men should not be separated from the surrounding social system (Sudjarwo, 2001:45-46). Furthermore, the data were analyzed by the method of hermeneutics. Hermeneutics is a system of interpretation to reveal the "hidden" meaning behind the text (Palmer, 2003:41). Hermeneutics is the decomposition process of getting out of the content and meaning that looks toward latent and hidden meanings (Palmer, 2003:48). Hermeneutic method does not seek the true meaning, but the most optimal meaning. Thus, the interpretation is done with the aim of explaining the meaning behind the literary text (Ratna, 2004: 45-46). The results of the analysis are presented descriptively

\section{Research Results}

\section{Synopsis of I Ceker Cipak}

I Ceker Cipak live with his mother in a village. They firm run dharma although deprived of his life. I Ceker Cipak very diligent work to make ends meet. He wants to sell. He was given a capital of 200 Kepeng by his mother to buy goods in the city. On the way into town, he saw cats, dogs, snakes, and mice were tortured by the citizens. He redeemed Cats, Dogs, Snakes with money each 50 coins, while Rat 25 kepeng redeemed with money because they feel sorry for. The residents are amazed to see the behavior I Ceker Cipak. He did not care and immediately passed to continue the journey to the city of the king. They arrived at the King City market when it was getting dark. I Ceker Cipak feel very hungry. The money is only the remaining 25 kepeng and used to buy food and was forced off to buy corn for sale.
When I Ceker Cipak together four beasts ransom was busy eating, suddenly the soldiers who patrol the palace came to him and asked him he had come to the city of kings. Soldiers also told the case to the king, and he was allowed to stay in the palace by the King. Until tonight, I Ceker Cipak could not remember her mother's bed and the money that has been depleted. Suddenly the snake crept approached him and talk. I Ceker Cipak startled. The Snake convey a message to him in order to ransom his mother named Dragon Gombang. We want to go home, the king equip cloth, money, and ten corn connective. I Ceker Cipak back to his village. Message the Snake implemented by I Ceker Cipak and he was rewarded with magical ring. Since having the magical ring, I Ceker Cipak become rich, but he remains diligent work and very generous. Magical ring was broken due to wear pounding rice. When repaired, exchanged rings with fake ring by ring maker. I Ceker Cipak sad. Seeing the sadness of his master, the Cats, Dogs and Rats, agreed to take a question in a Magical ring ring maker (the goldsmith). Cats clawing duty door of the house, so the goldsmith out. Cats and Dogs bite and scratch her legs so that the goldsmith was unconscious. Rat duty took the ring, and then handed over to the ring master. I Ceker Cipak very fond of his animals, he was getting richer, and eventually married a princess. Their lives are very happy and prosperous in the palace.

\section{Values Education as Reference Character Formation}

By reading the story can be seen the behavior of every character. Below, described the behavior of characters that need to be extremely important and imitated.

(1) The nature of religious (a reflection of man's relationship with God)

- Figures I Ceker Cipak and his mother is a character of a religious nature. They obey the dharma.

Dharma means truth, obligations.

- Character King and warrior implicitly religious nature because they have good behavior.

(2) The nature of honest, hard working, creative, independent, responsibility, tolerance, discipline, friendship/ communicative, social care, democratic, curiosity, the spirit of nationalism, patriotism, peace-loving, caring

environment (a reflection of man's relationship with man, man's relationship with nature)

- Character I Ceker Cipak are honest, hard working, creative, independent, tolerant, democratic, curiosity, love peace, care for the environment, social care, and responsibility.

- Character mothers have the nature of honest, hard work and responsibility.

- Character servicemen have honest nature, tolerance, curiosity, the spirit of nationalism, patriotism, love of peace, care for the environment, social care, and responsibility.

- Character King has the nature of honesty, tolerance, democratic, curiosity, the national spirit, love of peace, environmental care, social care, and responsibility.

- Character cats, dogs, snakes, and mice has a tolerance, respect, creativity, care for the environment, social care, and responsibility

\section{Volume 4 Issue 11, November 2015}




\section{International Journal of Science and Research (IJSR) \\ ISSN (Online): 2319-7064}

Index Copernicus Value (2013): 6.14 | Impact Factor (2014): 5.611

\section{Conclusion}

I Ceker Cipak story as an object of this article contains the values of education. Educational values which have been described above, can be used as a reference for the formation of character. Therefore, it is necessary and very important imitated.

\section{References}

[1] Bahtiar. 2012. "Kearifan Lokal Orang Bajo dalam Pengelolaan Sumber Daya Laut". Dimuat dalam jurnal terakreditasi Mudra, Jurnal Seni Budaya, Vol.27, No.2 Juli 2012, hlm178-185, ISSN 0854-3461. Denpasar: Institut Seni Indonesia.

[2] Creese, Helen. 1998. Parthayana: The Journeying of Partha, an Eighteenth-century Balinese Kakawin. Leiden: KITLV Press.

[3] Halliday, M.A.K. dan Ruqaiya Hasan. 1994. Bahasa, Konteks, dan Teks: Aspek-aspek Bahasa dalam Pandangan Semiotik Sosial. Terjemahan dari Language, Contex, and Text: Aspects of Language in a Socialsemiotik Perspective. Penerjemah Drs. Asrudin Barori Tou, M.A. Yogyakarta: Gajah Mada University Press.

[4] Karmini, Ni Nyoman. 2008. "Sosok Perempuan dalam Teks Geguritan di Bali: Analisis Feminisme". Disertasi. Denpasar: Universitas Udayana.

[5] Karmini, Ni Nyoman. 2011. Teori Pengkajian Prosan Fiksi dan Drama. Denpasar: Pustaka Larasan bekerja sama dengan Saraswati Institut Press.

[6] Karmini, Ni Nyoman. 2012. "Analisis Feminisme dalam Geguritan Saci." Dimuat dalam jurnal terakreditasi Dikti, Mudra, Jurnal Seni Budaya, Volume 27, No. 2 Juli 2012, hlm 141-154, ISSN:0854-3461. Denpasar: Institut Seni Indonesia.

[7] Kleden, Ignas. 2004. Sastra Indonesia dalam Enam Pertanyaan: Esai-Esai Sastra dan Budaya. Jakarta: Pustaka Utama Grafiti.

[8] Mulyani, Siti. 2012. "Upaya Mengungkap Peranan Kearifan Lokal sebagai Acuan untuk Pembentukan Pekerti Bangsa." Jurnal Ikadbudi, Jurnal Ilmiah Bahasa, Sastra, dan Budaya Daerah, Volume 1, Nomor 1, Februari 2012, ISSN 2089-7537. Yogyakarta: Ikatan Dosen Budaya Daerah se-Indonesia bekerja sama dengan Jurusan Pendidikan Bahasa Daerah Fakultas Bahasa dan Seni Universitas Negeri Yogyakarta.

[9] Palmer, R.E. 2003. Hermeneutika: Teori Baru Mengenai Interpretasi. Judul Asli: Hermeneutics: Interpretation Theory in Schleirmacher, Dilthey, Heidegger, and Gadamer. Penerjemah Musnur Hery dan Damanhuri Muhammed. Yogyakarta: Pustaka Pelajar.

[10] Putra, I Nyoman Darma. 2009. „'Kidung Interaktif Vocalising and interpreting traditional literature through electronic mass media in Baliee, Indonesia and the Malay World, 37:109, pp. 249-276.

[11] Putra, I Nyoman Darma. 2011. A literary Mirror; Balinese Reflections on Modernity and Identity in the Twentieth Century. Leiden: KITLV Press.

[12] Putra, I Nyoman Darma dan Helen Creese. 2012. "More than just ,numpang nampange; Women's participation in interactive textual singing on Balinese radio and television", Indonesia and the Malay World, October, 40:118, pp. 272-297

[13] Putra, I Nyoman Darma. 2014. "Popularizing Religious Values through Textual Singing on Interactive Radio and TV Programmes in Bali", The Journal of Hindu Studies, 7 (2), pp. 273-295.

[14] Ratna, I Nyoman Kutha. 2004. Teori, Metode, dan Teknik Penelitian Sastra: dari Strukturalisme hingga Postrukturalisme Perspektif Wacana Naratif. Yogyakarta: Pustaka Pelajar.

[15] Sudewa, I Ketut. 2006. "Pemberdayaan Karya Sastra Indonesia pemberdayaan Bangsa" dimuat dalam Jurnal Pustaka, Jurnal Ilmu-ilmu Budaya, Volume V, No.12 Tahun 2006, ISSN 0215-9198. Fakultas Satra Universitas Udayana.

[16] Sudjarwo, H. 2001. Metodologi Penelitian Sosial. Bandung: Mandar Maju.

[17] Tinggen, I.N. 1994. Aneka Sari Gending-gending Bali. Denpasar: Rhika Dewata.

[18] Todorov, T. 1985. Tata Sastra. Jakarta: Djambatan. 